\title{
History of establishment and evaluation of Ottoman-Turkish urology inside the surgical science
}

\author{
Ayhan Verit, ${ }^{1}$ Ahmet Urkmez, ${ }^{2}$ Sedat Tellaloglu ${ }^{3}$ \\ ${ }^{1}$ Department of Urology, University of Health Sciences Faculty of Medicine, Fatih Sultan Mehmet Training and Research Hospital, Istanbul, Turkey \\ ${ }^{2}$ Department of Urology, University of Health Sciences Faculty of Medicine, Haydarpasa Training and Research Hospital, Istanbul, Turkey \\ ${ }^{3}$ Department of Urology (Retaired), Istanbul University Faculty of Medicine, Istanbul, Turkey
}

\begin{abstract}
The first urological international organization occurred in Paris in 1908, and three Ottoman urologists were present among a total of 29. In that year, the Ottoman Urological society had only nine urologists, and almost all were from the Ottoman minorities with the exception of two under the main branch of General Surgery. Among them, Cemil Pasha who was the first dean and department chief of Surgery and Urology of the Medical School in a modern manner (1909) was the most dominant pioneer of the Turkish Surgery-Urology. Four beds out of 20 were separated for the urology clinic.

Keywords: History of urology; Ottoman; Turkish.

Cite this article as: Verit A, Urkmez A, Tellaloğlu S. History of establishment and evaluation of Ottoman-Turkish urology inside the surgical science. North Clin Istanb 2019;6(3):317-319.
\end{abstract}

$\mathrm{T}$ he Ottoman Empire (1299-1922) was an important historical region located at the center of the ancient three continents with Istanbul as the capital and settled near Bosporus, which is the border between Europe and Asia. Although the nineteenth century was regarded the declining period of the Empire, modern activities also had begun in this period. A western type Medical education were attempted to develop in this period. During the dissolution period in the early twentieth century, the Ottoman and German collaboration had increased in every aspect [1]. The military held the leading position in this regard. Ottoman's first medical academy, Gülhane Military Medical Academy, was established with the contributions of the German physicians Prof., MD R. Rieder and G. Deycke in Istanbul in 1898 [2, 3]. Dr. Reider was the pioneer in the usage of ether instead of chloroform for the anesthesia as a medical revolution during the sur- gical procedures in Ottoman medicine [4]. Meanwhile, in the Europe, since the improvement of surgical techniques along with the development of the surgical devices, national urological associations were established during the late nineteenth century. The French urological association established is 1896 was an initiative in urology with an idea to collaborate with the national associations under the international umbrella. This idea was realized in 1908 in Paris under the presidency of Prof. Guyon [5].

In the same period, Ottoman Urology saw the day light with a few urologists under the influence of French school who attempted to revolutionize all the fields of Ottoman Medicine. Among the 29 delegates of the first international committee, Dr. Tomasos Sgurdeos, from RUM [Greek of Turkish citizenship] Hospital Ka$z$ hçȩ̧me-Istanbul was an Ottoman urological delegate. Dr. Andrea Antippas and Dr. Leon Lacombe, both from

This manuscript was presented in European Association of Urology (EAU) Annual Congress, History section; P-374, Munich, March 11-15, 2016.

Received: November 08, 2017 Accepted: February 21, 2018 Online: August 14, 2018

Correspondence: Dr. Ayhan VERIT. Saglik Bilimleri Universitesi Tip Fakultesi, Fatih Sultan Mehmet Hastanesi, Uroloji Klinigi, Atasehir, Istanbul, Turkey.

Tel: +90216578 3000 e-mail: veritayhan@yahoo.com

(c) Copyright 2019 by Istanbul Provincial Directorate of Health - Available online at www.northclinist.com 


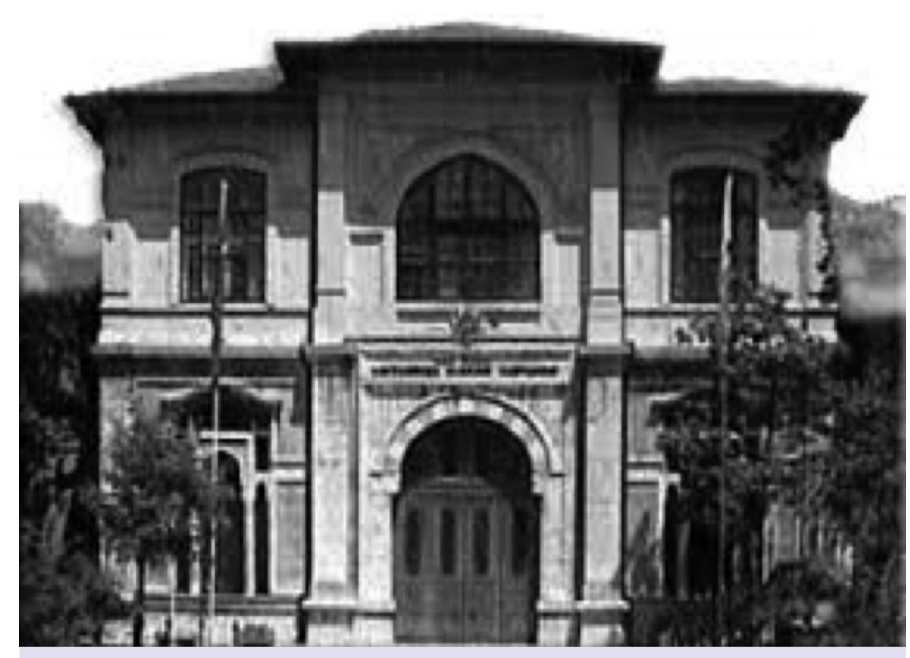

FIGURE 1. The first medical faculty in a modern manner was formed with the combination of military and civil medical schools at Haydarpasha Hospital in the year 1909.
Istanbul, also participated in the congress under the Turkish title. In the year 1908, the Ottoman Urological national association had a total nine urologists under the main branch as General Surgery who were from Istanbul with one exception of Izmir, a city located at the shore of Aegean (Dr. Psaltoff from Izmir RUM Hospital). All, except two, of these members originated from Ottoman minorities. In the following years, the interest in Urology had begun to increase among the Turkish medical population [5, 6]. Meanwhile, the first medical faculty in the modern world was formed with the combination of military and civil medical schools at Haydarpasha Hospital in the year 1909 (Fig. 1) [3-6]. Moreover, Ottoman urology was given the same reorganization with a 4-bed unit under the discipline of General Surgery [7]. Cemil Topuzlu Pasha was an important figure of the surgical sciences and connected with the nine Urologists (Fig. 2). He was one of the pioneers of Ottoman-Turkish Urologists, trained in Paris (1887) in Prof. Guyon's clinic, and a founded member of the French Urologic Society and some other European surgical associations. He was the first dean of the faculty and department Chief of General Surgery and conducted many invasive procedures in almost all surgical fields [3, 8-10]. Cemil Pasha approved Dr. Alexandre Pappas (also a brilliant painter) who also had Urologic training in Paris for a director with the title of associated professor of this pioneer four-bed Urology unit of Medical Faculty. Dr. Pappas separated from the Medical Faculty in 1908, settled in Greece, positioned as the Health minister for a period, and continued his

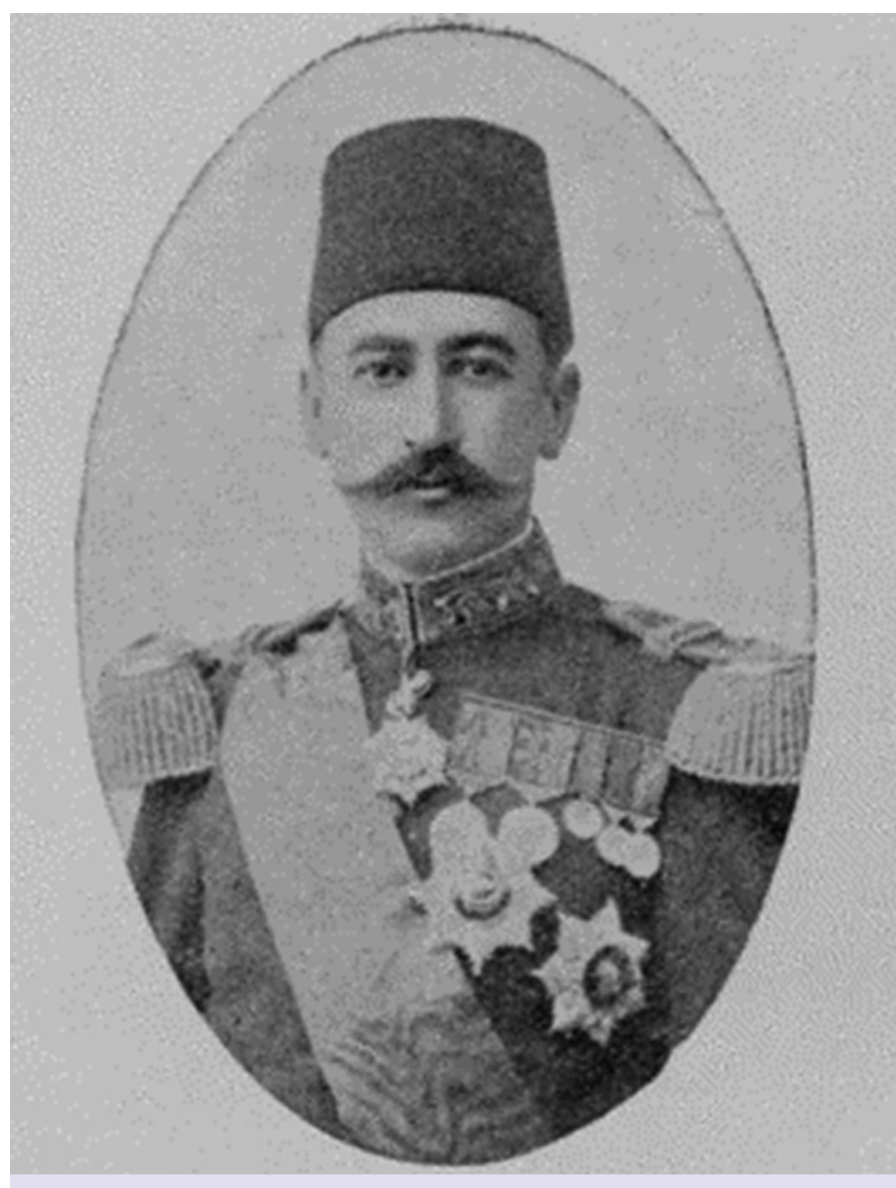

FIGURE 2. Cemil Topuzlu Pasha (1866-1958), the founder of Modern surgery, and Urology in particular, in Ottoman-Turkey.

life in Athens (Fig. 3). The first Urology resident (Prof. Sabit Erduran) was on duty at 1915 and now the Urology clinic has 20 beds and can be an independent department $[7,11]$. However, the long period of wars, such as First World War and subsequent Turkish independence war, interrupted the development of this academic scenario. Cemil Pasha was also involved in Ottoman Official Bureaucracy. He conducted the position of "Mayor of Istanbul province" for the period of 1912-1920 [3]. Then, he was elected as Ottoman Minister of "public works" in the last years of the Empire. In fact, Cemil Pasha was also a private doctor of Sultan V. Mehmet Reşad (19091918) who suffered from bladder stones for 6 years [12]. Thus, the rapid and early improvement of Turkish Urology can be attributed to the Sultan Reşad's Urological health problem that negatively contributed to the quality of life for many years until his surgery in 1915 [12]. It is not considered an exaggeration to mention that Sultan's stones were the milestones of Ottoman-Turkish Urology because the training facilities in Europe were under the 


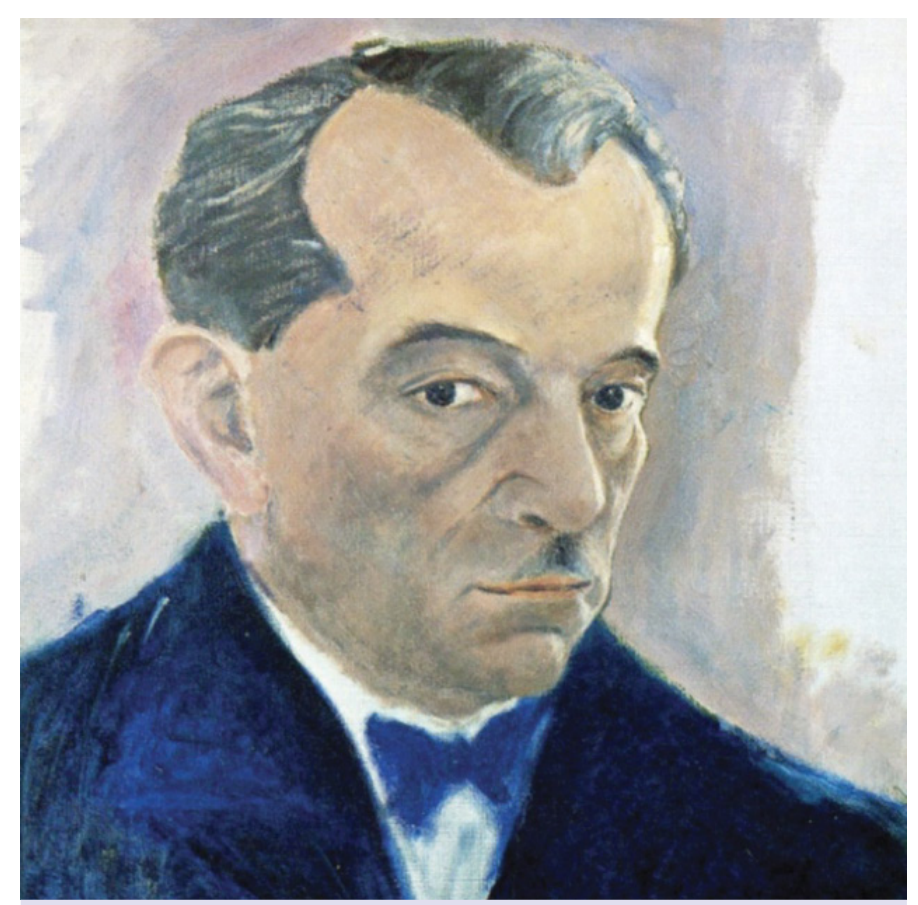

FIGURE 3. Dr. Alaexandre Pappas (1877-1942; self-portrait), teaching staff of the first urology department.

permission of Sultan. During this period, the Ottoman State trained nearly 60 educational staff in Europe to comprise the staff of Istanbul University under the confirmation of Sultan [6].

Since the Ottoman officials did not prefer to use the name of "Turkey" in official communications, the official notes of the first international Urological association (The former form of Societe International d Urologie -SIU-, 1908) interestingly pointed to delegates of "Turquie," which is the name of subsequent Turkish state that established later in 1923 [5]. In our opinion, the Ottoman urologist as also the high educated political figures of the country had already realized that their empire was in ending period ; thus, the idea of a new state with its special name was formed with a modern era under the influence of French type nationalism. SIU separated during World War I (WWI) and was reestablished in Paris in 1919. However, in that period, such international scientific societies were under the influence of politics, and the defeated nations of WWI, such as Germany, Ottoman Empire and Austria, were not reaccepted to the association. This point of view did not change in the next SIU meeting in 1924, although
Ottoman Empire had recently been collapsed, as already had realized by the Urologists, and a new Turkish republic was born after an independent war.

Despite of the ongoing political, sociocultural discussions, whether the state of Ottoman-Turkey within or outside Europe, Turkish Urology has been already involved in the history of European Urological community since the beginning. This process gave rise to the quick development of Turkish urology as a separate branch many years earlier rather than the other modern surgical departments of Turkey.

Conflict of Interest: No conflict of interest was declared by the authors.

Financial Disclosure: The authors declared that this study has received no financial support.

Authorship Contributions: Concept - AV, AU, ST; Design - AV, AU, ST; Supervision - AV, AU, ST; Materials - AV, AU, ST; Data collection and/or processing - $\mathrm{AV}, \mathrm{AU}, \mathrm{ST}$; Analysis and/or interpretation - AV, AU, ST; Writing - AV, AU, ST; Critical review - AV, AU, ST.

\section{REFERENCES}

1. https://en.wikipedia.org/wiki/Ottoman_Empire. Accessed Jul 25, 2019.

2. https://tip.sbu.edu.tr/GenelBilgiler/Tarihce

3. Ataç A. 19. Yüzyılda Türkiyéde Cerrahinin Gelişimi ve Op. Dr. Cemil Topuzlu Paşa. Ankara Üniversitesi Osmanlı Tarihi Araştırma Merkezi Dergisi, 2004:16:65-71. [CrossRef]

4. Akpir K. History of Anesthesiology in Turkey. Lokman Hekim Journal 2013;3:53-67.

5. Solok V. Uluslararası üroloji birliğinin kuruluşu, I ve II uluslararası kurultayları ve Osmanlı hekimleri. Cerrahpaşa Tıp Fakültesi Dergisi $1975 ; 6: 127-36$.

6. Solok V. Three names in the urology of Ottoman period. Turk J Urol 2010;36:219-25. [CrossRef]

7. Solok V. Foundation of urology in Turkey and Professor Behçet Sabit Erduran (in the memory of $25^{\text {th }}$ anniversary of his death). Turk J Urol 2006;32:153-161.

8. Batirel HF, Yüksel M. Cemil Topuzlu Pacha and his arterial suture technique. Ann Thorac Surg 1997;64:1201-3. [CrossRef]

9. Mut M, Dinç G, Naderi S. On the report of the first successful surgical treatment of brain abscess in the Ottoman Empire by Dr. Cemil Topuzlu in 1891. Neurosurgery 2007;61:869-72. [CrossRef]

10. Karatepe M, Tomatir E, Bozkurt P. The resuscitation greats. Cemil Topuzlu Pasha: one of the forgotten pioneers in the history of open chest cardiac massage. Resuscitation 2006;68:179-83. [CrossRef]

11. Solok V. Prof. Dr. Behçet Sabri Erduran, 1886-1980. Turk J Urol 1980;6:153-8.

12. Altıntaş A, Sınar N. Sultan Reşat'in Ameliyatı. Tarih ve Medeniyet 1997;34:50-3. 